\title{
Effect of herbicides and Sesbaniaco- culture on weed management and grain yield of direct seeded rice variety Khumal-4 at Khumaltar condition, Nepal
}

\author{
RK Bhattarai ${ }^{1}$, DD Gautam ${ }^{1}$, JD Ranjit ${ }^{1}$ and BS Chauhan ${ }^{2}$ \\ ${ }^{1}$ Agronomy Division, Khumaltar, NARC, ${ }^{2}$ International Rice Research Institute,
}

Philippines

Email: rkbhattrai@gmail.com

\section{Abstract}

Field experiments were conducted at the experimental field of Agronomy Division, Khumaltar, Nepal during 2012 and 2013 to find the effect of different herbicides on weed management and grain yield of direct seeded rice. The experiment was carried out in a Randomised Complete Block Design (RCBD ) with seven treatments in three replications. Khumal-4 rice variety was used with in all the seven treatments viz; W1 = Weedy Check (no weeding); W2 = Farmers practice ( two hand weeding); W3 = Pyrazosulfuron (pre) @ $20 \mathrm{~g}$ a.i /ha fb ( followed by ) Bispyribac (post-emergence (post) @ $25 \mathrm{~g}$ a. i / ha ; W4 = Pyrazosulfuron (pre) @ $20 \mathrm{~g}$ a.i /ha fb Bispyribac (post) @ $25 \mathrm{~g}$ a. i / ha fb 2, 4-D; W5= Oxadiargyl (pre-emergence (pre) @ $90 \mathrm{~g}$ a.i/ha fb Bispyribac (post)@ $25 \mathrm{~g}$ a. i / ha; W6= Oxadiargyl (pre) @ $90 \mathrm{~g}$ a.i /ha fb Bispyribac (post) @ $25 \mathrm{~g}$ a. i / ha fb 2, 4- D @ $500 \mathrm{~g} \mathrm{a} \mathrm{.i} \mathrm{/ha;} \mathrm{W7} \mathrm{=} \mathrm{Sesbania} \mathrm{(soaked)} \mathrm{fb} \mathrm{2,} \mathrm{4-} \mathrm{D} \mathrm{@} 500 \mathrm{~g} \mathrm{a.i} / \mathrm{ha} \mathrm{fb}$ one hand weeding. Rice seeds were directly sown by seed drill machine at seed rate of 30 $\mathrm{kg} / \mathrm{ha}$. All the pre emergence herbicides were sprayed on the first day of rice sowing whereas the post emergence herbicides were sown on 20 -25 days after sowing (DAS) by using a knapsack sprayer. Sesbania seed were sown at $30 \mathrm{~kg} / \mathrm{ha}$ as co-culture with rice on the same day as rice was sown by broadcasting. The Sesbania was knocked down at 30 DAS using 2, 4-D.The yield of rice in 2013 was less than that of 2012 which could be due to the less rainfall and uneven rain distribution during the rice season. The results showed that among the Pyrazosulfuron (pre) @ $20 \mathrm{ga}$ a.i /ha fb Bispyribac (post) @ $25 \mathrm{~g}$ a. i / ha $\mathrm{fb} 2,4-\mathrm{D}$ was found effective in controlling weed population, biomass and producing highest grain yield of rice $6512 \mathrm{~kg} / \mathrm{ha}$ in 2012 and $3190 \mathrm{~kg} / \mathrm{ha}$ in 2013 followed by the treatment Sesbania co-culture (Soaked) fb 2, 4- D @ $500 \mathrm{~g}$ a.i/ ha fb one and weeding giving increased rice yield of $6499 \mathrm{~kg} / \mathrm{ha}$ in 2012 and $2858 \mathrm{~kg} / \mathrm{ha}$ in 2013 .

Key Words: Sesbania co-culture, direct seeded rice, herbicides, grain yield and yield components of rice

\section{Introduction}

Rice is the main staple crop in Nepal .The conventional puddle -transplanted rice is the major system of rice production in the country. This system of rice production is becoming less profitable and less sustainable due to the high labour cost, high water and energy requirements. In addition, puddling operation affects soil due to the dispersion of soil 
particles as result soil become compact and making tillage operations difficult in succeeding crops such as wheat (Singh et al., 2002\& Hoobs et al., 2002).

Most of the labour force engaged in agricultural activity are attracted to non -farm jobs such as civil construction, garments and overseas works. There is an alternative option available to this transplanting system of rice is the direct seeded rice (Bhattarai et al., 2014).There are many advantages from direct seeded rice such as timely planting, less water use and early maturity of crops (Ranjit et al., 2013). However, aerobic or direct seeded rice are subject to much higher weeds pressure than conventional puddle transplanting system (Rao et al.,2007).Weeds account for 50 -80\% yield reduction in rainfed uplands rice (Ranjit et al., 1989).

Hand weeding is the most popular method of weed management in Nepal likewise in other developing countries of SAARC regions. Most of the upland and direct seeded rice grower in Asia weed their crops two to three times time using mechanical labour investing around 190 persons days/ ha ${ }^{1}$ in hand weeding (Roder ,2001). Herbicides are found to be alternative or supplement options to hand weeding. De Datta et al., (1996) and Singh et al., (2006) reported that pre and post emergence herbicides are effective if properly used in aerobic rice. The main problem of weeds in direct seeded rice (DSR) can only be solve if right pre and post emergence herbicides are selected. All the herbicides cannot control all the weeds in DSR. The intercropping of Sesbania with rice (co-culture) is a common practice of weed management in developed countries. The effective control of weeds in DSR by Co-culture of Sesbania which is commonly known as Dhaincha, is reported by Singh et al.,( 2007). Much works on pre and post emergence herbicides and use of Sesbania co -culture has not been done in Nepal. Therefore, this experiment was conducted to find the effect of different herbicides and Sesbania co-culture in weed management in direct seeded rice.

\section{Materials and methods}

Field experiments were conducted during 2012 and 2013 in the experimental field of Agronomy Division, Nepal Agricultural Research Council, Khumaltar, Nepal. The experiment was established in 5th and 7th of June during 2012 and 2013, respectively. The cropping system of the research site representing the mid-hills condition was rice -wheat. Rice was planted in normal season of rice growing during June-November. The geographical location of the site was 1360 meters (altitude), $27^{0} 40^{\prime} \mathrm{N}$ (latitude) and $85^{0}$ 20 'E (longitude) and the soil was clay loam with $\mathrm{pH}$ 5.6.The total rainfall received during the crop season (June to November ) was $1078.3 \mathrm{~mm}$ (2012) and $1024.3 \mathrm{~mm}$.(2013).

In the experiment a total of seven treatments were used for dry seeded rice to see their performance in RCB design in three replications. The individual plot size was $4.0 \mathrm{~m} \times 2.4$ 
$\mathrm{m}\left(9.6 \mathrm{~m}^{2}\right)$ and the rice variety used was Khumal-4, a fine grain most popular variety in the mid- hills of Nepal. The seed rate was $30 \mathrm{~kg} / \mathrm{ha}$ as directly sown in the field with two wheel tractor drawn Chinese seed drill. Sesbania used as the co-culture treatment was seeded at $30 \mathrm{~kg} / \mathrm{ha}$ soaked in water for 24 hours. The row spacing was $15 \mathrm{~cm}$.The chemical fertilizer was applied at the rate of 100: $40: 30 \mathrm{~kg} / \mathrm{ha}$ of $\mathrm{N}: \mathrm{P}_{2} \mathrm{O}_{5}: \mathrm{K}_{2} \mathrm{O}$.The whole dose of phosphorus and potash and $20 \mathrm{~kg}$ of nitrogen was applied as basal during the sowing time and $40 \mathrm{~kg}$ each of nitrogen was top dressed at tillering and panicle initiation (PI ) stage. The crop was given three irrigations, first during early crop establishment, rest two at tillering and PI stages. All the chemical herbicides were applied using flat fan nozzle by a Knap sack sprayer. The weed data were taken from a fixed quadrat of size $1 \times 1 \mathrm{~m}^{2}$ at 45 days after sowing (DAS) and classified into broadleaf, grasses and sedges. All other yield and yield attributing data wer recorded as per the Standard evaluation system of rice developed by the IRRI. The straw and the grains yield were taken after leaving the 2 borders rows. The data were analysed using the MSTAT-C package.

\section{Treatment details:}

\section{Treatment with notation (W1-W7)}

W1: Weedy Check

W2:Farmers' practice ( 2 Hand weeding )

W3:Pyrazosulfuron (pre) @ $20 \mathrm{~g}$ a.i /ha Followed By( fb ) Bispyribac (post) @ 25 g a. i / ha

W4: Pyrazosulfuron (pre) @ $20 \mathrm{~g}$ a.i /ha fb Bispyribac (post) @ $25 \mathrm{~g}$ a. i / ha Fb 2, 4 D

W5: Oxadiargyl (pre) @ 90 g a.i/ha fb Bispyribac (post) @ 25 g a. i / ha

W6:Oxadiargyl (pre) @ 90 g a.i /ha fb Bispyribac (post)@25 g a.i / ha Fb 2, 4- D @ $500 \mathrm{~g} \mathrm{a} . \mathrm{i} / \mathrm{ha}$

W7: Sesbania co-culture (Soaked) fb 2, 4- D @ 500 g a.i/ ha Fb 1 Hand weeding

\section{Results and discussion}

\section{Weed Population and dry biomass}

The result showed significant reduction in weed population in the herbicides treatments than in the weedy check. The major weeds observed infesting the experiment were; Commelina diffusa, Commelina benghalensis, Echinochloa crusgalli, Echinochloa colona, Cyperus iria, Cyperus sangunolutus, Fimbristylis, sp., Cyperus difformis. The less number of broadleaf weed recorded in the treatment ( W3, W4, W5 and W6) were less than than the weedy check (Table 1) which showed highest broadleaf number (220 in 2012 and 99 in 2013). In case of grassy weeds there was no significant difference in weed population among the treatments which might be due to the continuous rainfall after the pre emergence herbicide application. In case of sedges, it was found reduction in number in 
the herbicides treatments and highest sedges recorded in the weedy check treatments (91 in 2012 and 273 in 2013).Similar results of reduction of weeds number due to herbicides were reported by Hasanuzzaman et al ,2009). Weed dry biomass was recorded significantly less in the herbicides treatments than in the weedy check in broadleaf weed and sedges whereas, there was no significant difference in sedges dry biomass.

Table 1. Number of weed population (per $\mathrm{m}^{2}$ ) at $45 \mathrm{DAS}$ as affected by treatments during 2012-2013 normal rice growing season, Khumaltar, Nepal

\begin{tabular}{lllllll}
\hline Treatments & \multicolumn{3}{c}{ Broadleaf } & \multicolumn{2}{c}{ Grasses } & \multicolumn{2}{c}{ Sedges } \\
& $\mathbf{2 0 1 2}$ & $\mathbf{2 0 1 3}$ & $\mathbf{2 0 1 2}$ & $\mathbf{2 0 1 3}$ & $\mathbf{2 0 1 2}$ & $\mathbf{2 0 1 3}$ \\
\hline W1 & 220 & 99 & 100 & 25 & 91 & 273 \\
W2 & 184 & 75 & 112 & 6 & 107 & 191 \\
W3 & 23 & 80 & 72 & 16 & 14 & 156 \\
W4 & 29 & 27 & 106 & 11 & 37 & 130 \\
W5 & 11 & 12 & 70 & 18 & 14 & 234 \\
W6 & 41 & 8 & 79 & 13 & 12 & 175 \\
W7 & 98 & 77 & 62 & 24 & 98 & 146 \\
aF-test & $* *$ & $* *$ & $\mathrm{~ns}$ & $\mathrm{~ns}$ & $* *$ & \\
LSD( 0.05) & 103 & 62 & & & 68 & Ns \\
CV \% & 28 & 30 & \multicolumn{4}{c}{26} \\
\hline a $* * *$ and ns indicate significant at $\mathrm{P}<0.5, \mathrm{P}<0.05$ and not significant
\end{tabular}

Table 2. Weed dry biomass (per $\mathrm{m}^{2}$ ) at 45 DAS as affected by treatments during 20122013 normal rice growing season, Khumaltar, Nepal

\begin{tabular}{lllllll}
\hline Treatment & \multicolumn{2}{c}{ Broadleaf } & \multicolumn{2}{c}{ Grass } & \multicolumn{2}{c}{ Sedges } \\
& $\mathbf{2 0 1 2}$ & $\mathbf{2 0 1 3}$ & $\mathbf{2 0 1 2}$ & $\mathbf{2 0 1 3}$ & $\mathbf{2 0 1 2}$ & $\mathbf{2 0 1 3}$ \\
\hline W1 & 84 & 14 & 62 & 32 & 39 & 103 \\
W2 & 86 & 3 & 62 & 3 & 52 & 48 \\
W3 & 11 & 2 & 61 & 19 & 4 & 35 \\
W4 & 6 & 1 & 81 & 8 & 8 & 21 \\
W5 & 1 & 1 & 66 & 6 & 2 & 93 \\
W6 & 7 & 1 & 61 & 5 & 3 & 60 \\
W7 & 15 & 2 & 45 & 9 & 49 & 27 \\
aF-test & $* *$ & $* *$ & ns & ns & $* *$ & $* *$ \\
LSD( 0.05) & 49 & 6 & & & 32 & 40 \\
CV \% & 32 & 29 & & \multicolumn{4}{c}{27} & 35 \\
\hline a $*, * *$ and ns indicate significant at $\mathrm{P}<0.5, \mathrm{P}<0.05$ and not significant
\end{tabular}

\section{Plant growth and yield attributes}

The data on plant growth showed that plant height in weed control treatment were more than the weedy check (tTble 3). The use of Sesbania co-culture (Soaked) fb 2, 4- D @ $500 \mathrm{~g}$ a.i/ ha fb one hand weeding (W7) produced crop with tallest plant height $142 \mathrm{~cm}$ in 
2012 and $117 \mathrm{~cm}$ in 2013). The maximum crop height in this treatment might be due to the competition between Sesbania and rice for light, moisture and space. The yield attributes like tillers $/ \mathrm{m}^{2}$ and filled grains/panicle showed the higher value in the herbicides treatments than the weedy check (Table 3). The treatment W4 recorded 169 tillers / $\mathrm{m}^{2}$ in 2012 and 236 tillers $/ \mathrm{m}^{2}$ in 2013 .This treatment also showed the higher number filled grains/panicles 190 in 2012 and 182 in 2013 whereas other yield attributes like 1000 grains weight were recorded not significant. However, unfilled grains/panicles showed significant result in 2013 only.

Table 3. Growth and yield attributes of rice as affected by treatments during 20122013 normal rice growing season, Khumaltar, Nepal

\begin{tabular}{|c|c|c|c|c|c|c|c|c|c|}
\hline \multirow[t]{2}{*}{ Treatments } & \multicolumn{2}{|c|}{ Plant } & \multicolumn{2}{|c|}{ Tillers/m² } & \multirow[b]{2}{*}{ Mean } & \multicolumn{2}{|c|}{$\begin{array}{l}1000 \text { grains } \\
\text { weight }(g)\end{array}$} & \multicolumn{2}{|c|}{$\begin{array}{l}\text { Number of unfilled } \\
\text { grains/panicle }\end{array}$} \\
\hline & 2012 & 2013 & 2012 & 2013 & & 2012 & 2013 & 2012 & 2013 \\
\hline W1 & 120 & 96 & 94 & 96 & 95 & 18.3 & 19.0 & 11 & 5 \\
\hline W2 & 131 & 109 & 182 & 208 & 195 & 18.8 & 19.0 & 16 & 8 \\
\hline W3 & 134 & 112 & 190 & 207 & 198 & 18.8 & 19.0 & 12 & 21 \\
\hline W4 & 137 & 113 & 169 & 236 & 202 & 18.5 & 19.5 & 10 & 6 \\
\hline W5 & 131 & 104 & 200 & 148 & 174 & 18.1 & 19.5 & 14 & 6 \\
\hline W6 & 132 & 111 & 216 & 169 & 192 & 18.2 & 19.2 & 12 & 6 \\
\hline W7 & 142 & 117 & 137 & 194 & 165 & 18.7 & 19.1 & 10 & 5 \\
\hline${ }^{\text {a}} \mathbf{F}$-test & $* *$ & $* *$ & $* *$ & $* *$ & & ns & ns & ns & $* *$ \\
\hline $\operatorname{LSD}(0.05)$ & 10.6 & 11.6 & 65.6 & 64.6 & & & & & 12.6 \\
\hline CV \% & 7 & 5.9 & 20.2 & 12 & & & & & 14 \\
\hline
\end{tabular}

\section{Grain yield}

The grain yield of rice in all the herbicides and Sesbania treatment showed higher than the weedy check (Table4). Grain yield differences were significant among the treatments. The grain yield in 2012 was higher than in 2013 due to more rainfall and even distribution of rains in the rice critical stages of rice under study. The treatment, Pyrazosulfuron (pre) @ $20 \mathrm{~g}$ a.i /ha fb Bispyribac (post) @ $25 \mathrm{~g}$ a. i / ha fb 2, 4 -D (W4) recorded the highest grain yield of $6512 \mathrm{~kg} / \mathrm{ha}$ in 2012 and $3190 \mathrm{~kg} / \mathrm{ha}$ in 2013 . Thi trend was followed by the treatment, Sesbania co-culture (Soaked) fb 2, 4- D @ $500 \mathrm{~g}$ a.i/ ha fbone hand weeding (W7) with grain yield of $6499 \mathrm{~kg} / \mathrm{ha}$ in 2012 and $2858 \mathrm{~kg} / \mathrm{ha}$ in 2013 which was statistically at par with the treatment W4. Similar result of higher yield due to the use of herbicides was also reported by Bhurer et al (2013). The result of straw yield of all the treatments were higher than the weedy check and insignificant. 
Table 4. Grain yield and yield components of rice as affected by the treatments during 2012-2013 normal rice season, Khumaltar, Nepal

\begin{tabular}{|c|c|c|c|c|c|c|c|c|}
\hline \multirow[t]{2}{*}{ Treatments } & \multicolumn{3}{|c|}{ Filled grains/panicle } & \multicolumn{2}{|c|}{ Straw yield (kg/ha) } & \multicolumn{3}{|c|}{ Grains yield (kg/ha) } \\
\hline & 2012 & 2013 & Mean & 2012 & 2013 & 2012 & 2013 & Mean \\
\hline W1 & 169 & 130 & 149 & 3513 & 1667 & 3178 & 657 & 1917 \\
\hline W2 & 187 & 139 & 163 & 5267 & 3573 & 5351 & 2698 & 4024 \\
\hline W3 & 204 & 150 & 177 & 5810 & 3590 & 4051 & 2271 & 3161 \\
\hline W4 & 190 & 182 & 186 & 5340 & 4326 & 6512 & 3190 & 4851 \\
\hline W5 & 204 & 152 & 178 & 6007 & 1993 & 4687 & 1485 & 3086 \\
\hline W6 & 202 & 172 & 187 & 5730 & 2930 & 4648 & 1835 & 3241 \\
\hline W7 & 197 & 183 & 190 & 6103 & 4263 & 6499 & 2858 & 4678 \\
\hline & & & & & & & $\mathrm{s}$ & \\
\hline aF-test & Ns & $* *$ & & ns & Ns & $* *$ & & \\
\hline $\operatorname{LSD}(0.05)$ & & 31 & & & & 2164 & 1467 & \\
\hline CV \% & & 11 & & & & 18 & 22 & \\
\hline
\end{tabular}

\section{Acknowledgements}

The Authors like to extend sincere their thanks to NARC and IRRI for funding the project. Help received from the team members of the Agronomy Division involved in this project are highly acknowledged.

\section{References}

Bhattarai, RK; JD Ranjit; and DD Gautam. 2014. Effect of dates of sowing and varieties on growth, weeds infestation, and yield of direct seeded rice in rice- wheat cropping system in the mid -hills of Nepal. Proceedings. of 27 National Summer crops workshop, vol 2, Pp . 282-287.

Bhurer , KP; DN Yadav; JK Ladha; RB Thapa; and K Pandey. 2013. Effect of integrated weed management practices on performance of dry direct seeded rice (Oryza sativa L.). Agronomy J of Nepal, Vol.3: 53-63.

De Datta, SK and AM Beltazar. 1996. Weed control technology as a component of rice production system. Auld, BA, Kim, KU (Eds.), Weed management in rice, FAO plant production and protection paper 139, pp, 27-52.

Hasanuzzaman, Mirza; MH Ali; MM Ala;, M Akther; and K F Alam. 2009. Evlauation of preemergence herbicide and hand weeding on the weed control efficiency and performances of transplanted Aus rice. American-Eurasian J of Agronomy 2 (3): $138-143$

Hobbs,PR; Y Singh; GS Giri; JG Lauran; and JM Duxbery. 2002. Direct seeding and reduced tillage options in the rice- wheat systems of the Indo - gangetic plains of south Asia. Direct seeding in Asian Rice systems, strategic Research Issues and opportunities .International Rice Research Institute, Philippines, pp. 201 -215 
Ranjit, JD; KP Bhurer; GP, Koirala; Y,Thakur; and DN, Chaudhary. 1989. Screening of herbicides in uplands and transplanting rice, Proceedings of 14th summer crops Workshop, Parwanipur, Nepal, pp. 129- 139

Rodder W. 2001. Slash and burn rice system in the hills of northers Lao PDR. Description, challenges and opportunities IRRI, Philippines, pp.201.

Singh, SR; S Chhokar; R Gopal; JK Ladha; RK Gupta; V Kumar; and M Singh. 2007.Integrated weed management. A key to success for direct seeded rice in the Indo-gangetic plains. Integrated Crop and Resources Management in the ricewheat System of south Asia.pp.261- 270. 